\title{
Response to I. Batinic-Haberle et al.
}

Citation for published version (APA):

Schmidt, H. H. H. W., Stocker, R., Paulsen, G., Ghezzi, P., Riley, D., Daiber, A., \& Cuadrado, A. (2016). Response to I. Batinic-Haberle et al. Antioxidants \& Redox Signaling, 24(9), 525-526.

https://doi.org/10.1089/ars.2016.29029.hhs

Document status and date:

Published: 20/03/2016

DOI:

10.1089/ars.2016.29029.hhs

Document Version:

Publisher's PDF, also known as Version of record

Document license:

Taverne

Please check the document version of this publication:

- A submitted manuscript is the version of the article upon submission and before peer-review. There can be important differences between the submitted version and the official published version of record.

People interested in the research are advised to contact the author for the final version of the publication, or visit the DOI to the publisher's website.

- The final author version and the galley proof are versions of the publication after peer review.

- The final published version features the final layout of the paper including the volume, issue and page numbers.

Link to publication

\footnotetext{
General rights rights.

- You may freely distribute the URL identifying the publication in the public portal. please follow below link for the End User Agreement:

www.umlib.nl/taverne-license

Take down policy

If you believe that this document breaches copyright please contact us at:

repository@maastrichtuniversity.nl

providing details and we will investigate your claim.
}

Copyright and moral rights for the publications made accessible in the public portal are retained by the authors and/or other copyright owners and it is a condition of accessing publications that users recognise and abide by the legal requirements associated with these

- Users may download and print one copy of any publication from the public portal for the purpose of private study or research.

- You may not further distribute the material or use it for any profit-making activity or commercial gain

If the publication is distributed under the terms of Article $25 \mathrm{fa}$ of the Dutch Copyright Act, indicated by the "Taverne" license above, 


\title{
Response to I. Batinic-Haberle et al.
}

\author{
Harald H.H.W. Schmidt, ${ }^{1}$ Roland Stocker, ${ }^{2,3}$ Gøran Paulsen, ${ }^{4}$ Pietro Ghezzi, Dennis Riley, \\ Andreas Daiber, and Antonio Cuadrado ${ }^{8-11}$
}

To the Editor:

$\mathbf{T}$ He LetTer By Batinic-Haberle et al. (3) in response to our review (7) is symptomatic for our exciting field of redox biology and medicine, although we disagree with its aggressive and in part nonscientific style. Their focus appears to be on redox biology, whereas the focus of our review was on redox medicine, in particular those drugs and applications already in clinical practice or in advanced clinical development rather than of "potential" or "future" clinical relevance. It was beyond the scope of our review to address the wide field of redox biology or experimental antioxidant reagents. Batinic-Haberle et al. (3) provide a good overview of redox-active compounds that, based on preclinical data, might hold some promise for clinical developments [see table 1 in (3)]. To our knowledge, however, just a few of these compounds had entered a phase I trial at the time of writing our review, and none of them had progressed to phase II. One exception is mitoQ for which several phase II trials have been carried out in Parkinson's disease, aging, nonalcoholic fatty liver disease, and hepatitis $\mathrm{C}$, although none of these trials has been conclusive. In addition, the phase III study 2CARE for Huntington's disease has been halted prematurely as a result of lack of efficacy of coenzyme $\mathrm{Q}_{10}$ (http:// huntingtonstudygroup.org/tag/2care/).

Batinic-Haberle et al. (3) specifically criticize that superoxide dismutase (SOD) mimetics were not mentioned, when in fact our review did mention some of these compounds, although maybe not the ones favored by these authors. AEOL 10150 may be an interesting antioxidant, but it has been at an early clinical stage of development for many years. Moreover, a phase I trial with amyotrophic lateral sclerosis (also known as Lou Gehrig's disease and Charcot disease) patients in 2005 did apparently not progress, and in January 2015, the FDA put a clinical hold on AEOL 10150 (www.marketwired .com/press-release/aeolus-announces-response-fda-clinicalhold-plan-clinical-development-aeol-10150-otcqb-aols1981367.htm). MnSOD mimetics were also discussed in cancer prevention and chronic obstructive pulmonary disease, but clinical trials are lacking (5). Other related compounds for which the authors of the letter appear to have a special interest, such as BMX-010 and BMX-001, are, to our knowledge, still in phase I, and we note that some of the authors of the letter hold patents for some of these compounds (4) and are supported by the company developing them (i.e., Biomimetix Pharmaceutical, Inc).

Conversely, the SOD mimetic mentioned in our review, GC4419, as being, at that time, in phase IIa was meanwhile shown to protect patients from side effects of radiotherapy (www.evaluategroup.com/Universal/View.aspx?type=Story \&id=616252). Based on these clinical trial results, the US FDA has granted "Fast-Track" status to this agent in December 2015 and the compound is now in a phase IIb/IIIa human clinical trial in the United States at several major cancer treatment centers and shall be completed in approximately 1-2 years. To the best of our knowledge, this development stage is the most advanced in the field and it is thus appropriate to have focused on this compound.

We note that the letter of Batinic-Haberle et al. (3) also contains a textbook-style lecture on SOD catalysis being a one-electron process. We agree, of course, that true SOD catalysis is a one-electron process. However, the same is not the case for the $\mathrm{Mn}$ (porphyrin) complexes described by Batinic-Haberle et al. (3), as these also carry out multiple electron processes. For example, the same group reported $\mathrm{Mn}$ (porphyrin) complexes to also be good "catalase",

\footnotetext{
${ }^{1}$ Department of Pharmacology and Personalised Medicine, Cardiovascular Research Institute Maastricht, Faculty of Health, Medicine and Life Sciences, Maastricht University, Maastricht, the Netherlands.

${ }^{2}$ Victor Chang Cardiac Research Institute, Sydney, Australia.

${ }^{3}$ University of New South Wales, Sydney, Australia.

${ }^{4}$ Norwegian School of Sport Sciences, Oslo, Norway.

${ }^{5}$ Brighton \& Sussex Medical School, Brighton, United Kingdom.

${ }^{6}$ Galera Therapeutics, Inc., Malvern, Pennsylvania.

${ }^{7}$ Labor für Molekulare Kardiologie, Zentrum für Kardiologie, Universitätsmedizin der Johannes Gutenberg-Universität, Mainz, Germany.

${ }^{8}$ Centro de Investigación Biomédica en Red sobre Enfermedades Neurodegenerativas (CIBERNED), ISCIII, Madrid, Spain.

${ }^{9}$ Instituto de Investigaciones Biomédicas "Alberto Sols" UAM-CSIC, Madrid, Spain.

${ }^{10}$ Instituto de Investigación Sanitaria La Paz (IdiPaz), Madrid, Spain.

${ }^{11}$ Department of Biochemistry, Faculty of Medicine, Autonomous University of Madrid, Madrid, Spain.
} 
mimics (2) and others described them as efficient peroxynitrite decomposition catalysts (8). Thus, they are not only selective for superoxide removal but also react with the product of the dismutation, hydrogen peroxide, and the secondary oxidant, peroxynitrite. This may or may not be clinically useful or relevant, but mechanism is something that must be noted when discussing pharmacology of a pharmaceutical agent.

Furthermore, it is irritating that the authors attempt to discount other compounds that are currently in human clinical trials [e.g., $\mathrm{Mn}(\mathrm{II})$ pentaazamacrocyclic ligand complexes] by claiming that they are acid unstable. This is misleading given that some of the authors of this letter have reported previously on the high kinetic and thermodynamic stability of members of this class of compounds (e.g., M40403) (6). In fact, compounds of this class, including GC4419, are largely unmetabolized ( $>90 \%$ unchanged) and excreted almost entirely intact (1).

In summary, given the focus of our review on the advanced clinical stage of antioxidant drugs, we consider it free of obvious bias, including conflict of interest. By comparison, it would have been appropriate for the authors of the letter, in the version provided to us, to state any potential conflict of interest that may have contributed to their choice of compound(s).

\section{References}

1. Aston K, Rath N, Naik A, and Slomczynska U. Computeraided design (CAD) of Mn (II) complexes: Superoxide dismutase mimetics with catalytic activity exceeding the native enzyme. Inorg Chem 40: 1779-1789, 2001.

2. Batinic-Haberle I, Tovmasyan A, and Spasojevic I. An educational overview of the chemistry, biochemistry and therapeutic aspects of Mn porphyrins - From superoxide dismutation to H2O2-driven pathways. Redox Biol 5: 43-65, 2015.

3. Batinic-Haberle I, Tovmasyan A, and Spasojevic I. Antioxidants in translation medicine-Commentary. Antioxid Redox Signal 24: 518-524, 2016.

4. Evans MK, Tovmasyan A, Batinic-Haberle I, and Devi GR. Mn porphyrin in combination with ascorbate acts as a prooxidant and mediates caspase-independent cancer cell death. Free Radic Biol Med 68: 302-314, 2014.
5. Robbins D and Zhao Y. Manganese superoxide dismutase in cancer prevention. Antioxid Redox Signal 20: 1628-1645, 2014.

6. Salvemini D and Riley DP. Nonpeptidyl mimetics of superoxide dismutase in clinical therapies for diseases. Cell Mol Life Sci 57: 1489-1492, 2000.

7. Schmidt HHHW, Stocker R, Vollbracht C, Paulsen G, Riley D, Daiber A, and Cuadrado A. Antioxidants in translational medicine. Antioxid Redox Signal 23: 1130-1143, 2015.

8. Valez V, Cassina A, Batinic-Haberle I, Kalyanaraman BB, Ferrer-Sueta G, and Radi R. Peroxynitrite formation in nitric oxide-exposed submitochondrial particles: Detection, oxidative damage and catalytic removal by Mn-porphyrins. Arch Biochem Biophys 529: 45-54, 2013.

Address correspondence to: Dr. Antonio Cuadrado

Instituto de Investigaciones Biomédicas "Alberto Sols" UAM-CSIC C/Arturo Duperier 4 Madrid 28029

Spain

E-mail: antonio.cuadrado@uam.es

Dr. Harald H.H.W. Schmidt

Department of Pharmacology and Personalised Medicine

CARIM

FHML

Maastricht University

P.O. Box 612

6200 MD Maastricht

The Netherlands

E-mail: h.schmidt@maastrichtuniversity.nl

Date of first submission to ARS Central, January 29, 2016; date of acceptance, February 6, 2016.

\section{Abbreviation Used}

$\mathrm{SOD}=$ superoxide dismutase 